\title{
21. INTERSTITIAL WATER STUDIES ON SMALL CORE SAMPLES, DEEP SEA DRILLING PROJECT, LEG $3^{1}$
}

\author{
F. T. Manheim, ${ }^{2}$ U. S. Geological Survey, Woods Hole, Massachusetts \\ and \\ K. M. Chan, D. Kerr and W. Sunda, Woods Hole Oceanographic Institution, Woods Hole, Massachusetts
}

\section{INTRODUCTION}

Eleven samples of fluids which had been squeezed on board ship, and four, packaged sediment samples were received in our laboratories. As in Leg 2, the volumes of fluid available were scanty and did not permit multiple determinations of constituents in many of the samples; in Hole 21 the fluid available sufficed only for refractometer readings (a few tenths of a milliliter). Therefore, analytical scatter is again responsible for partially obscuring variations (and constancy) in the conservative constituents such as sodium. However, on the whole the results confirm the features which appeared in Legs 1 and 2. Central oceanic sediments display a remarkable constancy in total salinity, chlorinity and sodium concentration to the greatest depths and ages yet penetrated in the project drillings. Variations attributable to postburial reactions do occur in the remaining major ions, but they usually show little systematic trend with depth-with the exception of potassium, which will be discussed later.

Methods remain similar to those employed for Leg 2; the detailed techniques are now being prepared for submission, but a brief description may be obtained from the previous Leg reports (Manheim and Sayles, 1969; Chan and Manheim, 1970). Results from four unsqueezed samples are not complete and, therefore, do not appear here.

\section{RESULTS AND DISCUSSION}

All measurements are reported in Table 1, together with brief sediment descriptions and ages from the preliminary log. Minor constituents could not be analyzed on Holes $20 \mathrm{C}$ and 21 due to the lack of sample fluid. The ocean basin samples (excluding Hole 21 on the Rio Grande Rise) showed salinities and chlorinities within 1 per cent (standard deviation) of mean values of $35.2 \mathrm{o} / \mathrm{oo}$ and $19.5 \mathrm{o} / \mathrm{oo}$, respectively. These values are insignificantly different from the Leg 2 means (17 samples) of 35.1 o/oo and 19.7 o/oo. On the other hand, the Rio Grande Rise samples (salinity and chloride of $36.1 \mathrm{o} / \mathrm{oo}$ and $20.6 \mathrm{o} / \mathrm{oo}$, respectively) are significantly higher than the mean.

\footnotetext{
${ }_{1}^{1}$ Woods Hole Oceanographic Institution Contribution No. 2410.

${ }^{2}$ Publication approved by Director, U. S. Geological Survey.
}

New results bearing on the distribution of potassium concentration in pore waters have just been communicated to the writers by J. L. Bischoff (Bischoff et al., 1969). Previously Mangelsdorf et al. (1969) noted that the reported values of potassium in oceanic pore waters consistently exceeded the potassium concentration in open ocean water. They showed that the diffusional flux of potassium into the ocean from pore waters might exceed the supply from the continents. These authors also performed an experiment on sea watersaturated bentonite which showed that raising the equilibrium temperature during squeezing of the sediments could raise interstitial potassium concentrations appreciably. Sodium was also enriched, though to a lesser extent; whereas, magnesium and, to a lesser extent, calcium compensated for the excess cations by being depleted in the pore waters. Pressure differences in the squeezing process did not appear to cause significant changes. The experiments by Bischoff and his co-workers were performed on natural clayey sediments from Southern California offshore basins and suggested an increase in interstitial potassium concentrations of about 10 per cent for each 18-degree temperature increase (i.e., from $4.5^{\circ}$ bottom-equivalent temperatures to $22.5^{\circ}$, laboratory temperatures).

The effects in question are assumed to be related to ion exchange behavior of the more reactive clay minerals, especially montmorillonite and illite. Only a minority of the Deep Sea Drilling Project samples run to date are as clay-rich as those sediments whose temperature-sensitive properties have been demonstrated to date. Nevertheless, it is clear that analytical values, especially for potassium, may be affected by the difference between in situ temperature (around 2 to $3^{\circ} \mathrm{C}$ for most of the oceanic samples) and squeezing temperatures (on the order of $21^{\circ} \mathrm{C}$ ). Experiments are planned to explore the influence of these effects on a range of materials collected by the Project. For the time being we suggest that a part, and sometimes all of potassium excesses noted in near-surface samples may be due to the change of temperature prior to squeezing. On the other hand, only a relatively small portion of the normal magnesium depletions are attributable to temperature effects, assuming that the equivalent ionic magnesium depletion does not exceed the equivalent ionic enrichment of potassium. Ten per cent enrichment in potassium 
TABLE 1A

Major Constituents in Interstitial Waters of Leg 3 Cores $^{\mathrm{a}}$

\begin{tabular}{|c|c|c|c|c|c|c|c|c|c|c|c|c|c|c|c|}
\hline $\begin{array}{l}\text { Sample } \\
\text { Designation }\end{array}$ & $\begin{array}{l}\text { Depth Below } \\
\text { Sea Bed } \\
(\mathrm{m})^{b}\end{array}$ & Age & Description & $\mathrm{Na}$ & K & $\mathrm{Ca}$ & $\mathrm{Mg}$ & $\begin{array}{l}\text { Total Cations } \\
(\mathrm{meq} / \mathrm{kg})^{\mathrm{e}}\end{array}$ & $\mathrm{Cl}$ & $\mathrm{SO}_{4}$ & Alk. & $\mathrm{HCO}_{3}^{\mathrm{d}}$ & $\begin{array}{l}\text { Total Anions } \\
(\mathrm{meq} / \mathrm{kg})^{\mathrm{e}}\end{array}$ & Sum & Salinity ${ }^{\mathrm{f}}$ \\
\hline \multicolumn{16}{|c|}{ Hole 13 ( $6^{\circ} 02.4^{\prime}$ S., $18^{\circ} 13.7^{\prime}$ W., water depth $\left.4685 \mathrm{~m}\right)$} \\
\hline $2-4$ & 23 & $\begin{array}{l}\text { Lower } \\
\text { Pliocene }\end{array}$ & $\begin{array}{l}\text { Brown silty } \\
\text { zeolitic clay, } \\
\text { Mn-stained }\end{array}$ & $10.7^{\mathrm{c}}$ & 0.47 & 0.45 & 1.24 & (603) & 19.5 & 2.26 & 5.6 & 0.34 & 603 & 35.0 & 35.2 \\
\hline $3-3$ & 140 & $\begin{array}{l}\text { Middle } \\
\text { Eocene }\end{array}$ & $\begin{array}{l}\text { Gray-yellow-green } \\
\text { sandy to silty } \\
\text { radiolarian ooze }\end{array}$ & $10.7^{\mathrm{c}}$ & 0.37 & 0.78 & 1.24 & (614) & 19.8 & 2.27 & 8.2 & 0.50 & 614 & 35.6 & 35.8 \\
\hline \multicolumn{16}{|c|}{ Hole $15\left(30^{\circ} 53.4^{\prime}\right.$ S., $17^{\circ} 59.0^{\prime} \mathrm{W} .$, water depth $\left.3927 \mathrm{~m}\right)$} \\
\hline $3-5$ & (40) & Pliocene & $\begin{array}{l}\text { White nannofossil } \\
\text { chalk }\end{array}$ & $11.0^{\mathrm{c}}$ & 0.42 & 0.40 & 1.29 & 615 & 19.7 & 2.59 & 5.6 & $0.3^{\mathrm{f}}$ & (615) & 35.0 & . \\
\hline $9-5$ & 136 & $\begin{array}{l}\text { Lower } \\
\text { Miocene }\end{array}$ & $\begin{array}{l}\text { Dark brown marly } \\
\text { nannofossil chalk } \\
\text { ooze }\end{array}$ & 10.8 & 0.43 & 0.42 & 1.20 & 600 & 19.1 & 2.44 & 6.1 & 0.37 & 596 & 34.5 & - \\
\hline \multicolumn{16}{|c|}{ Hole $19\left(28^{\circ} 32.1^{\prime}\right.$ 'S., $23^{\circ} 40.6^{\prime}$ W., water depth $\left.4677 \mathrm{~m}\right)$} \\
\hline $1-5$ & 7 & Miocene (?) & $\begin{array}{l}\text { Dark red-brown } \\
\text { zeolitic clay }\end{array}$ & 10.8 & 0.49 & 0.38 & 1.23 & 602 & 19.3 & 2.68 & 5.8 & 0.35 & 606 & 35.2 & - \\
\hline $8-4$ & 110 & $\begin{array}{l}\text { Middle } \\
\text { Eocene }\end{array}$ & $\begin{array}{l}\text { Light yellow-brown } \\
\text { nannofossil chalk ooz }\end{array}$ & $\mathrm{ze}^{11.0}$ & 0.44 & 0.38 & 1.23 & 610 & 19.6 & 2.53 & 4.0 & 0.24 & 609 & 35.4 & . \\
\hline $11-3$ & 136 & $\begin{array}{l}\text { Middle } \\
\text { Eocene }\end{array}$ & $\begin{array}{l}\text { Yellow-brown nan- } \\
\text { nofossil chalk ooze }\end{array}$ & $10.8^{\mathrm{c}}$ & 0.45 & 0.38 & 1.23 & 605 & 19.2 & 2.21 & $15^{\mathrm{d}}$ & $0.9^{\mathrm{d}}$ & (605) & 35.2 & - \\
\hline \multicolumn{16}{|c|}{ Hole $20 \mathrm{C} \quad\left(28^{\circ} 27^{\prime}\right.$ S., $26^{\circ} 58^{\prime}$ W., water depth approx. $\left.4500 \mathrm{~m}\right)$} \\
\hline $1-5$ & 8 & Oligocene & $\begin{array}{l}\text { Light yellow to } \\
\text { brown marly nan- } \\
\text { nofossil chalk ooze, } \\
\text { zeolitic-hematitic } \\
\text { in part }\end{array}$ & $11.0^{\mathrm{c}}$ & 0.49 & 0.35 & 1.24 & 610 & 19.6 & 2.60 & $3.3^{\mathrm{d}}$ & 0.20 & $(610)$ & 35.5 & - \\
\hline
\end{tabular}


TABLE 1A - Continued

\begin{tabular}{|c|c|c|c|c|c|c|c|c|c|c|c|c|c|c|c|}
\hline $\begin{array}{c}\text { Sample } \\
\text { Designation }\end{array}$ & $\begin{array}{l}\text { Depth Below } \\
\text { Sea Bed } \\
(\mathrm{m})^{\mathrm{b}}\end{array}$ & Age & Description & $\mathrm{Na}$ & $\mathrm{K}$ & $\mathrm{Ca}$ & $\mathrm{Mg}$ & $\begin{array}{l}\text { Total Cations } \\
(\mathrm{meq} / \mathrm{kg})^{\mathrm{e}}\end{array}$ & $\mathrm{Cl}$ & $\mathrm{SO}_{4}$ & Alk. & $\mathrm{HCO}_{3}{ }^{\mathrm{d}}$ & $\begin{array}{l}\text { Total Anions } \\
(\mathrm{meq} / \mathrm{kg})^{\mathrm{e}}\end{array}$ & Sum & Salinity ${ }^{\mathrm{f}}$ \\
\hline 3-1 & 37 & Eocene & As above & $10.8^{\mathrm{c}}$ & 0.46 & 0.36 & 1.28 & (603) & 19.4 & 2.51 & 3.8 & 0.23 & 603 & 35.0 & - \\
\hline Hole 21 & \multicolumn{15}{|c|}{$\left(28^{\circ} 35.1^{\prime}\right.$ S., $30^{\circ} 35.8^{\prime}$ W., water depth $\left.2113 \mathrm{~m}\right)$} \\
\hline $5-2$ & 100 & $\begin{array}{l}\text { Upper } \\
\text { Cretaceous } \\
\text { (Campian) }\end{array}$ & $\begin{array}{l}\text { Pink foraminifera- } \\
\text { nannofossil ooze }\end{array}$ & - & - & - & - & - & (20.6) & - & - & - & $\cdot$ & - & 36.2 \\
\hline $8-3$ & 130 & $\begin{array}{l}\text { Upper } \\
\text { Cretaceous } \\
\text { (Campian) }\end{array}$ & $\begin{array}{l}\text { Yellow-gray nan- } \\
\text { nofossil-foramini- } \\
\text { feran chalk }\end{array}$ & - & - & $\cdot$ & - & - & (20.5) & - & - & - & - & - & 36.1 \\
\hline
\end{tabular}

${ }^{\mathrm{a}}$ All values are in $\mathrm{g} / \mathrm{kg}$ unless otherwise noted. Standard deviations of reproducibility of the results are: $\mathrm{Na} 0.8, \mathrm{Cl} 0.1, \mathrm{~K} 0.01, \mathrm{Ca} 0.01, \mathrm{Mg} 0.02, \mathrm{SO} \mathrm{C}_{4} 0.03, \mathrm{Alkalinity} 0.1$. The above estimates are subject to modification, partly as noted below. As noted in previous reports $\mathrm{NH}_{4}$, though not determined here, is not thought to contribute significant error to the cation-anion balances, except possibly in Sample 19-11-3 (very high alkalinity).

$\mathrm{b}$ Depths below sediment surface are given to the nearest meter due to some uncertainty in position.

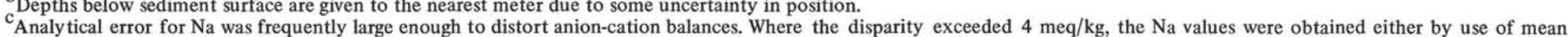
$\mathrm{Na} / \mathrm{Cl}$ ratios and $\mathrm{Cl}$ values, or by difference. The use of the former method is based on the fact that $\mathrm{Cl}$ is the most accurately known constituent in our analysis series and $\mathrm{Na} / \mathrm{Cl}$ $\mathrm{Na} / \mathrm{Cl}$ ratios and $\mathrm{Cl}$ values, or by difference. The use of the former method is based on the fact that $\mathrm{Cl}$ is the most accurately known constituent in our analysis series and $\mathrm{Na} / \mathrm{Cl}$ No values having superscript "c" have been determined by these methods.

$\mathrm{d}_{\mathrm{HCO}_{3}}$-is calculated from alkalinity, assuming that the alkalinity is entirely due to bicarbonate. This assumption is not strictly correct, due to the influence of borate, phosphate, silicate, carbonate, or other possible weak acids, but errors from this source are probably less than uncertainties associated with squeezing the waters from the cores, etc. Samples marked with " $\mathrm{d}$ " are determined by difference in cation-anion balance.

Total cations and anions, where shown in parentheses, are assumed to be equal to the oppositely charged species for the purpose of determining a constituent by difference.

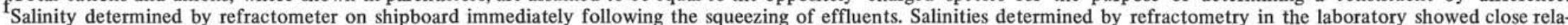
tionship with determined chlorinity values, and were used in Hole 21 samples to extrapolate chlorinity values. 
TABLE 1B

Minor Constituents in Leg 2 Interstitial Waters Composition (mg/kg) ${ }^{\mathrm{a}}$

\begin{tabular}{|c|c|c|c|c|c|c|c|}
\hline Sample Designation & $\begin{array}{l}\text { Depth Below } \\
\text { Sea Bed } \\
\text { (m) }\end{array}$ & $\mathrm{Sr}$ & $\mathrm{Li}$ & $\mathrm{Mn}$ & $\mathrm{Ba}$ & B & $\mathrm{S}$ \\
\hline \multicolumn{8}{|l|}{ Hole 13} \\
\hline $2-4$ & 23 & 7.6 & 0.28 & 2.9 & 0.19 & 7.0 & 9 \\
\hline $3-3$ & 140 & 11.0 & 0.18 & 1.7 & 0.10 & 3.0 & 29 \\
\hline \multicolumn{8}{|l|}{ Hole 15} \\
\hline $3-5$ & (40) & 13.4 & 0.19 & 2.9 & 0.25 & 3.0 & 26 \\
\hline $9-5$ & 136 & 13.0 & 0.25 & 0.9 & 0.15 & 2.0 & 10 \\
\hline \multicolumn{8}{|l|}{ Hole 19} \\
\hline $1-5$ & 7 & 12.6 & 0.25 & 1.3 & 0.10 & 8.0 & 10 \\
\hline $8-4$ & 110 & 13.6 & 0.15 & 1.5 & 0.27 & 5.5 & 12 \\
\hline
\end{tabular}

${ }^{\mathrm{a}}$ The reliability of the minor element determination is indicated approximately by the rounding of the data.

equals $1 \mathrm{meq} / \mathrm{kg}$. A compensating depletion in magnesium would amount to only 0.01 o/oo or less than 1 per cent of total magnesium.

The observations by Mangelsdorf et al. (1969) and Bischoff et al. (1969) must be taken account of in another effect which has been noted: the rather characteristic decrease of potassium concentrations in deeper layers. Thermal gradient data for deeper strata in the Atlantic are not available, but assuming they are roughly equivalent to those in geosynclinal sedimentary basins (about $3^{\circ} \mathrm{C} / 100$ meters) laboratory or shipboard temperatures would be approached at around 600 meters (1968 feet) depth. Moreover, bottom waters during earlier Tertiary time have been stated to be warmer than at present. Cooling of bottom waters in Pliocene-Recent time should, therefore, have also altered the temperature and interstitial ionic ratios of subbottom sediments to an increasing extent with proximity to the sediment-water interface.

Among the minor elements strontium and lithium show values equal to or moderately higher than sea water concentrations. Barium and manganese values are substantially higher than in Northern Atlantic sediments. Many of the samples displayed prominent brownish casts and other evidences of appreciable manganese concentrations; Hole 20 even bottomed in manganese nodules at only 6 meters ( 20 feet) depth. Therefore, it seems logical to assume that the relatively high manganese values are a result of partial reduction and solubility of high-manganese oxide layers on the surfaces of sediment particles. Since samples were all squeezed immediately after core recovery and the membrane ( 0.45 microns) filtered, the authors believe that the values are not an artifact of sample extraction or corehandling procedures. Boron shows typically erratic values, within a factor of 2 , of sea water concentrations; Silicon, obtained by emission spectrometry for the first time in the work on the Deep Sea Drilling Project cores, reveals values much higher than in overlying bottom waters, but it is typical for interstitial waters of oceanic sediments (e.g. Zaitseva, 1966). The influence of temperature effects on minor constituents remains unknown but will be investigated by the authors.

\section{REFERENCES}

Bischoff, J. L., Greer, R. E. and Luistro, A. O., 1969. Potassium enrichments in interstitial waters of marine sediments: evaluation of temperature of squeezing effect. Submitted for publication.

Chan, K. M. and Manheim, F. T., 1970. Interstitial water studies on small core samples, Deep Sea Drilling Project, Leg 2. In Peterson, M. N. A. et. al., 1970, Initial Reports of the Deep Sea Drilling Project, Volume II. Washington (U. S. Government Printing Office) pp. 359-363.

Mangelsdorf, P. C., Wilson, T. R. S. and Daniell, E., 1969. Potassium enrichments in interstitial waters of recent marine sediments. Science. 65, 171.

Manheim, F. T. and Sayles, F. L., 1969. Interstitial water studies on small core samples, Deep Sea Drilling Project, Leg 1. In Ewing, M, et. al., 1969. Initial Reports of the Deep Sea Drilling Project, Volume I. Washington (U. S. Government Printing Office) pp. 403-410

Zaitseva, E. D., 1966. Biogennye elementy (biogenic elements). In Khimiya Tikhogo okean. Pt. 2, S. W. Brujewiez (Ed.). Moscow (Izdat. Nauka) 309. 